\section{Building a New Energy Future with Wind Power}

Wind is a clean, domestic, renewable energy resource that can help America realize a secure energy future. Capturing the wind generates clean electricity and substantial economic benefits to communities all across the United States. A U.S. Department of Energy (DOE) report found that the wind energy could supply $20 \%$ of the nation's electricity by 2030, which would entail 300,000 megawatts (MW) of new wind generating capacity. The wind industry's rapid expansion in the past few years underscores the industry's significant potential to create jobs, spur economic activity, reduce water use, and reduce greenhouse gas emissions, all while producing clean electricity.

Wind offers a vast clean energy resource waiting to be tapped. A 2010 study found that the U.S. land-based wind resource is $10,000,000 \mathrm{MW}$, and the steady winds just off America's coasts only increase that massive resource. However, despite vast potential and rapid growth, China recently overtook the United States as the world's leader in installed wind capacity.

By the end of 2010, the United States had 40,180 MW of installed capacity, behind China's 42,287 MW. Leading the global clean energy economy requires the United States to capture a greater share of the world's total wind capacity, which now approaches 194,000 MW.

\section{Industry Growth}

Although industry growth in 2010 was slower than the record growth set in 2009, 5,600 MW worth of projects were under construction at the end of the year, laying the foundation for further growth in 2011. In 2010, the U.S. wind industry grew $15 \%$, installing 5,115 MW of generating capacity - enough to power more than 1.2 million homes. Wind power represented $25 \%$ of all new U.S. electric generation capacity in 2010. According to the American Wind Energy Association, 38 states now have utility scale wind projects. Current wind power installations in the United States provide enough electricity to avert nearly 62 million tons of greenhouse gas emissions, which is equivalent to taking 14 million cars off the road. Fourteen states have installed more than 1,000 MW of wind power.

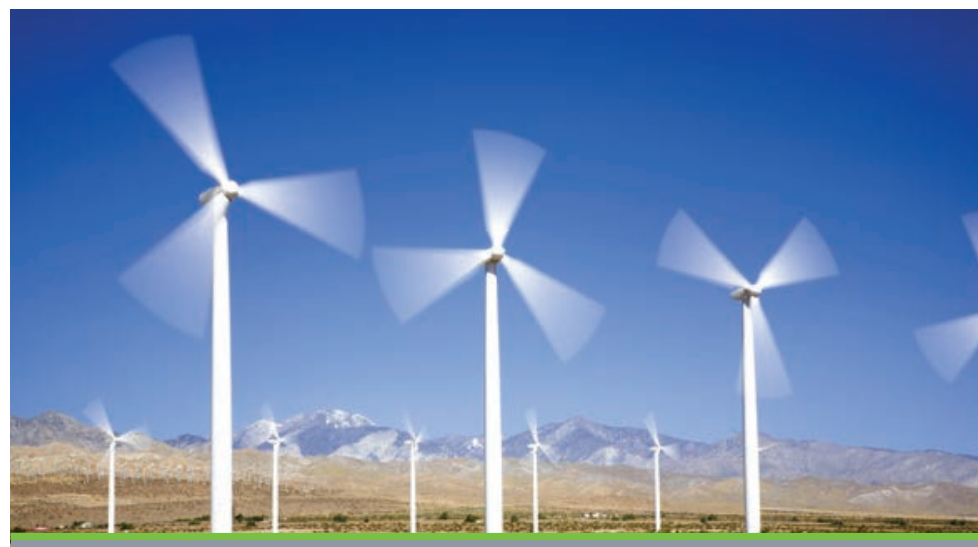

The potential U.S. land-based wind resource is about 10,000,000 megawatts. Photo by Iberdrola Renewables, NREL 16110

The renewable energy industry creates thousands of longterm, high-technology careers in wind turbine component manufacturing, construction and installation, maintenance and operations, legal and marketing services, transportation and logistical services, and more. In 2009 and 2010, the wind sector invested roughly $\$ 27$ billion in the U.S. economy and employed about 85,000 workers.

A modern wind turbine has more than 8,000 component parts. To supply this market, more than 100 U.S. manufacturing facilities have been brought online, announced, or expanded since 2007 . Today, more than 400 U.S. manufacturing plants serve the wind industry.

In addition to providing our nation with competitively priced electricity and high quality jobs, wind energy offers:

- Emissions-free electricity

- Job creation, especially in the construction and manufacturing sectors

- A domestic power source

- Rural economic development including increased tax bases for local governments

- Reductions in water use by traditional electric generating facilities.

\section{The National Investment in Wind Energy: Building on Success}

The Wind Program works with industry, DOE's national laboratories, state and local governments, and other federal agencies to advance wind technology and support the responsible wide-scale deployment of wind energy. 


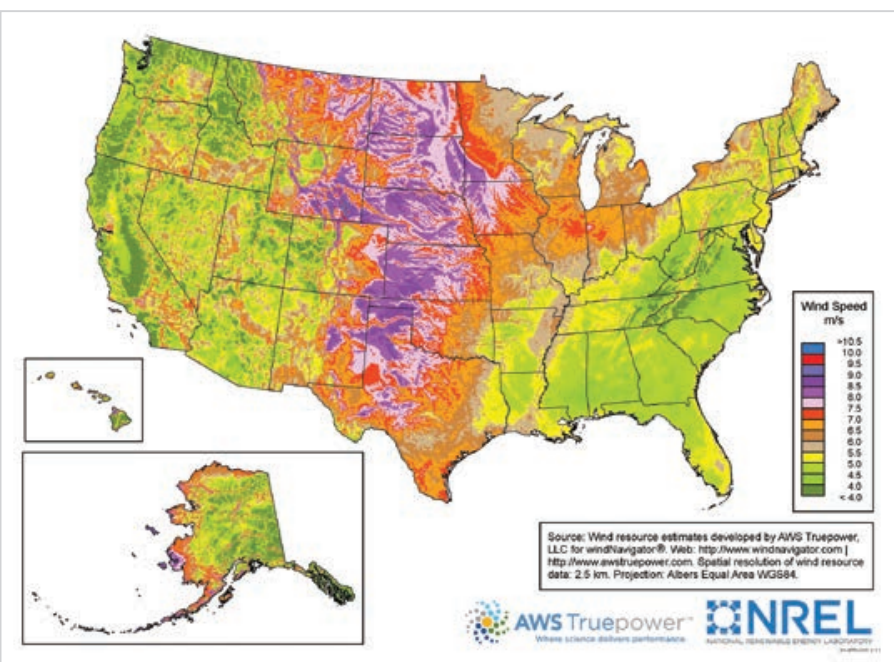

United States average wind speed at 80 meters (262 feet) above the ground.

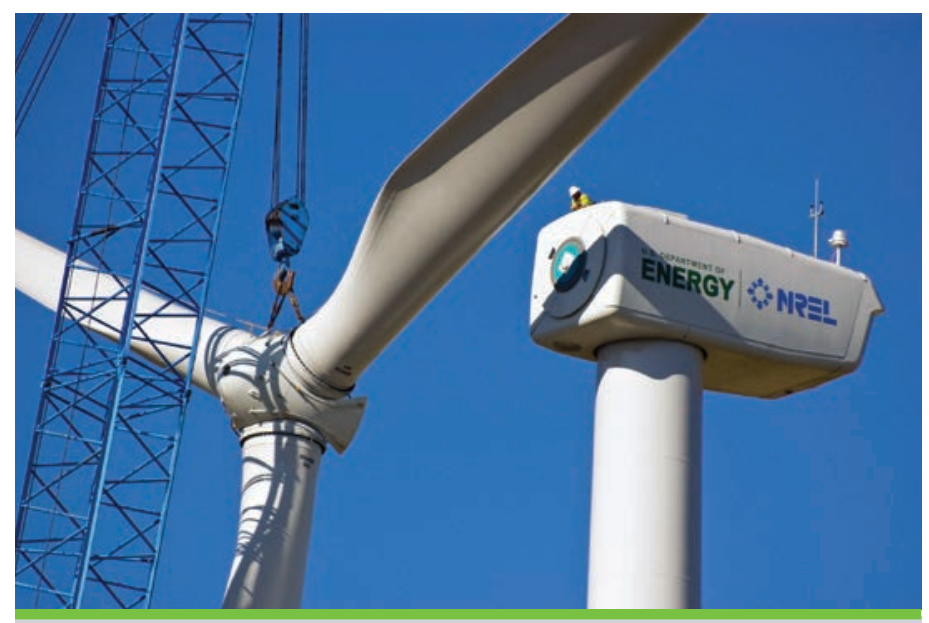

National Renewable Energy Laboratory technicians install DOE's 1.5-megawatt GE wind turbine at the National Wind Technology Center. Photo by Pat Corkery, NREL 16571
Previous partnerships led to turbine technology advances that have lowered the cost of wind energy from over 55 cents per kilowatt-hour in 1980 (current dollars) to under 6 cents per kilowatt-hour today.

DOE is building on this record of success with the following major efforts:

- Advancing large wind turbine technology: The program conducts competitively selected, cost-shared research and development projects with industry to further improve reliability, increase capacity factors, and decrease costs of large wind turbine technology. Current areas of focus include advanced rotor development, gearbox and blade reliability initiatives, design validation and modeling, and component testing.

- Boosting offshore wind development: The program collaborates with state and federal agencies, industry, and other stakeholders to promote and accelerate responsible offshore wind energy development in U.S. waters.

- Supporting grid interconnection: The program addresses interconnection impacts, electric power market rules, operating strategies, and system planning required to facilitate the integration of increasing amounts of wind energy into the nation's electric grid.

- Bolstering domestic manufacturing and creating jobs: The program helps industry develop robust and cost-effective manufacturing processes to strengthen the domestic supply chain for wind components, and it invests in programs to develop the skilled workforce needed for tomorrow's wind industry, both land-based and offshore

- Overcoming barriers to deployment: The program works with states and other stakeholders through its Wind Powering America outreach and education initiative as well as forums such as the National Wind Coordinating Collaborative. In order to overcome barriers to the expanded use of wind technology, the program provides objective and unbiased information on wind energy policy, siting, and the economic benefits and challenges of wind development.

\section{Learn More

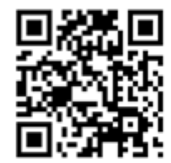 \\ wind.energy.gov}

For more information, visit: 